\title{
PENGARUH BAHASA
}

\section{TERHADAP PERKEMBANGAN KOGNISI ANAK}

\author{
Abdulloh Hadziq, M. Pd. I ${ }^{1}$ \\ IAIN Surakarta \\ Email: ab_hadziq@yahoo.com
}

\begin{abstract}
Abstrak
Bahasa memegang peranan penting dalam kehidupan manusia, khusunya dalam kegiatan berkomunikasi. Demikian pula peran bahasa bagi anak, bahasa memberi sumbangan yang signifikan dalam perkembangan anak menjadi dewasa. Piaget memandang bahwa anak memainkan peran aktif didalam menyusun pengetahuannya mengenai realitas, anak tidak pasif menerima informasi. Sehingga dengan kemampuan kognitif ini, anak akan mampu berkomunikasi sesuai dengan perkembangannya. Bahasa yang diwujudkan dalam sebuah kata-kata adalah bentuk representasi dari sebuah fakta, yang pada akhirnya mengklasifikasikan dalam kategori yang berbeda-beda dan memunculkan perbedaan budaya satu dengan budaya yang lain. Dengan demikian, bahasa mampu memfasilitasi potensi anak untuk menalar dan berfikir sehingga pengetahuan anak akan berkembang.
\end{abstract}

Kata Kunci: Bahasa, perkembangan kognisi, anak

\begin{abstract}
Language has an important role in human life, especially to communicate. And also for children, language gives significant contribution in their growth. Piaget saw that the children play important roles in constructing their knowledge about reality. The children are not taking the information passively. So, with their cognitive ability the children can communicate appropriate to their development. The language in the form of words is representation of fact which eventully will classify different categories and initiate the differentiation among cultures. Thus, the language assist children's potentials to comprehend and think so that their knowledge will be developed.
\end{abstract}

Keywords ; Language, Cognitive Development, Children

\footnotetext{
1 Dosen Fakultas Ilmu Tarbiyah dan Keguruan (FITK) IAIN Surakarta dan alumni pascasarjana pendidikan Guru Raudlatul Athfal (PGRA) UIN Sunan Kalijaga.
} 


\section{A. PENDAHUluan}

Usia dini merupakan usia yang sangat penting bagi perkembangan anak sehingga disebut golden age. ${ }^{2}$ Perkembangan anak usia dini adalah masa yang paling signifikan dalam kehidupan manusia. Jika diibaratkan dalam sebuah bangunan, jika pondasinya kokoh maka bangunannyapun kuat dan tahan lama, dan sebaliknya jika pondasinya rapuh maka bangunannya akan mudah roboh dan rusak. Untuk mencetak generasi yang lebih baik paling tidak pada masa ini pendidikan anak harus menjadi prioritas, agara nantinya menjadi generasi yang mampu menjadi kebanggaan bangsa dan Negara.

Pada masa ini, manusia pertama kali belajar atau diperkenalkan dengan suasana yang samasekali "baru". Dalam perkembangannya, anak mempunyai kebutuhan yang harus dipenuhi, dari sinilah keberadaan lingkungan berperan menjadi wadah segala aktifitas, baik lingkungan fisik ataupun social. Dan secara bertahap, bayi mulai memahami hubungan antar "kata" dengan apa atau siapa saja yang ada di sekitarnya. Dan untuk itu, bayi mulai memerlukan alat ekspresi yang disebut "bahasa".

Bahasa merupakan medium tanpa batas yang membawa segala sesuatu di dalamnya, yaitu segala sesuatu mampu termuat dalam lapangan pemahaman manusia. Bahasa juga menjadi media manusia berfikir secara abstrak sehingga obyek yang factual mampu ditransformasikan menjadi sebuah kata. Tidak heran ketika ada statement yang mengatakan bahwa "Dunia ada di mulut kita".

Namun perlu diketahui bahasa terkadang dapat juga memunculkan konflik antar sesama dan inilah yang harus menjadi catatan agar bagaimana nanti generasi kedepan mampu berbahasa

2 A. Martuti. Mendirikan dan Mengelola PAUD, Manajemen Administrasi dan Strategi Pembelajaran (Yogjakarta : Kreasi Wacana, 2009), hlm. 22 
dengan baik dan benar. Sehingga mampu mengantisipasi dan meminimalisir segala kemungkinan yang akan terjadi, seperti yang kita ketahui keberagaman sudah menjadi bagian dari bangsa kita. Oleh karena itu, segala perbeadan baik suku, ras, bahasa dan kenyakinan harus mampu kita sikapi dengan bijak.

Anak usia dini mulai belajar mengenal bahasa dari sekitarnya. Pemerolehan bahasa pada bayi berdampak pada keberlanjutan mereka dalam perkembangan berfikirnya. Oleh karena itu, dalam makalah ini, penulis akan membahas terkait dengan pemerolehan bahasa pada manusia khususnya pada anak dalam pengaruhnya terhadap kemampuan berfikirnya.

\section{B. PEMBAHASAN}

\section{Perkembangan Bahasa Pada Anak}

Bahasa bagi sebagian besar komunitas menjadi penting sebagai alat komunikasi dan menyampaikan pesan atas obyek yang dilihat ataupun didengarnya. Bahasa juga menjadi alat komunikasi di mana pikiran dan perasaan scseorang disimbolisasikan agar dapat menyampaikan arti kepada orang lain. Sehingga orang mampu berkomunikasi tanpa harus berada didekat obyek yang disampaikannya.

Menurut J. W. Santrok bahasa adalah bentuk komunikasi entah itu lisan, tertulis atau tanda yang didasarkan pada system symbol. Semua bahasa manusia adalah generative (diciptakan). Penciptaan tidak terbatas adalah kemampuan untuk memproduksi sejumlah kalimat tak terbatas yang bermakna dengan menggunakan seperangkat kata dan aturan. ${ }^{3}$

\footnotetext{
${ }^{3}$ John W. Santrock. Psikologi Pendidikan, terj. Tri Wibowo B.S. (Jakarta: Kencana, 2007), hlm. 67
} 
Pada usia antara 2 hingga 6 tahun, sebagaimana diungkapkan Berk, terdapat perkembangan yang begitu penting pada diri anak, terutama dalam perkembangan bahasa. Raihan luar biasa tersebut memperlihatkan keaktifannya, yakni suatu pendekatan yang berorientasi kepada penguasaan bahasa. ${ }^{4}$

Pada ranah pengembangan bahasa anak, yang ingin digapai adalah bagaimana kemampuan anak dalam menggunakan bahasa untuk pemahaman bahasa pasif dan dapat berkomunikasi secara efektif yang bermanfaat atau mengungkapkan pikiran dan belajar anak. ${ }^{5}$ Kemudian, penguasaan bahasa sendiri meliputi penguasaan kosakata, tata bahasa, dan percakapan

\section{a. Kosakata}

Dalam Development through the Lifespan, Laura E. Berk mengungkapkan bahwa ada anak yang menguasai 200 kata di usianya yang baru 2 tahun. Dia kemudian memprediksi jikalau anak tersebut akan menguasai sekitar 10000 kata pada usia 6 tahun. Bagaimana sebenarnya anak-anak membangun kemampuan penguasaan kosakatanya? Riset memperlihatkan bahwa anak-anak bisa menghubungkan kata-kata baru dengan beberapa konsep pokok setelah anak hanya mengalami sebuah perjumpaan. Proses ini dinamakan fast-mapping (pemetaan cepat). Anak prasekolah bahkan bisa memetakan dua atau lebih banyak kata-kata baru yang ia temui dalam situasi yang sama. ${ }^{6}$

\section{b. Jenis kata}

Untuk kata-kata yang belum dikuasai, anak usia 3 tahun mendapatkan kata-kata baru dari sosok/orang yang telah ia kenal.

\footnotetext{
${ }^{4}$ Laura E.Berk. Development through the Lifespan (Boston: Pearson, 2007), hlm. 248.

${ }^{5}$ Mansur. Pendidikan Anak Usia Dini dalam Islam (Yogyakarta: Pustaka Pelajar, 2009), hlm. 37.

${ }^{6}$ Laura E. Berk. Development.., hlm. 248.
} 
Misalnya, Sammy membuat kata gabung "plant-man" untuk mengacu pada "gardener". Suatu waktu, ia menambahkan -er pada crayon sehingga menjadi "crayoner" untuk menyebut anak yang suka bermain krayon. Anak prasekolah juga menggunakan pemaknaan bahasa melalui metaphor, seperti anak usia 3 tahun yang menggambarkan stomachache dengan ungkapan "fire engine in my tummy" yang berarti mesin berapi dalam perutnya.

Sekali kosakata dan pengetahuan umum itu berkembang, anak juga memberikan apresiasi pada perbandingan nonsensorik, "teman itu seperti magnet". Anak kecil juga kadang-kadang berkomunikasi dengan penuh bersemangat dan dengan cara yang mengesankan. ${ }^{7}$

\section{c. Strategi Mempelajari Kata}

Anak-anak prasekolah memahami arti kata-kata baru dengan cara membandingkan kata-kata tersebut dengan kata-kata yang telah mereka kenal. Namun konsep apa yang sebenarnya mereka gunakan ternyata belum bisa pasti mudah dipahami. Salah satu spekulasi yang muncul yaitu anak-anak mengadopsi a mutual exclusivity bias (prasangka yang saling terpisah). Anak-anak berasumsi bahwa kata-kata itu merujuk pada kategori-kategori yang terpisah. Dengan pemikiran ini, ketika anak usia 2 tahun diberitahu dua nama/obyek baru (misalnya jepitan dan tanduk), anak tersebut kemudian menentukan masing-masing kata dengan benar, yang mengacu kepada keseluruhan obyek, bukan sebagian.

Di lain kesempatan, anak-anak memahami banyak arti kata dengan mengamati bagaimana kata-kata tersebut digunakan dalam struktur kalimatnya. Anak-anak juga memanfaatkan cukup banyak informasi sosial yang diberikan oleh orang dewasa ketika

${ }^{7}$ Ibid. 
diperkenalkan dengan kata-kata baru. Sebagai contoh, anak-anak menggunakan kemampuannya untuk menyimpulkan maksud atau cara pandang orang lain.

Hunt dan Beglar mendiskusikan tiga pendekatan dalam pengajaran dan pembelajaran kosakata, yaitu belajar insidental (pemerolehan insidental), yaitu pembelajaran kosakata sebagai produk sampingan dari melakukan hal-hal lain seperti membaca atau mendengarkan; intruksi yang eksplisit (tegas), dan pengembangan strategi bebas. Sebuah sumber utama pembelajaran insidental adalah membaca ekstensif yang hunt dan beglar rekomendasikan sebagai aktivitas luar kelas reguler. Intruksi eksplisit tergantung pada identifikasi yang spesifik kosatarget akuisisi untuk anak. Informasi sekarang tersedia pada apa target tersebut harus untuk anak pada tingkat kemahiran yang berbeda. ${ }^{8}$

Jika tidak ada isyarat sosial atau informasi secara langsung, anak-anak seusia 2 tahun akan sangat fleksibel dalam strategi pembelajaran kata-nya. Mereka dengan simple-nya memperlakukan suatu kata baru yang diterapkan pada suatu obyek sebagai sebutan kedua bagi obyek tersebut. ${ }^{9}$

\section{d. Perkembangan Kosakata Anak}

Anak-anak memperoleh kosakata secara efisien dan akurat sebagaimana yang diyakini para ahli. Dengan naluri bawaannya, anak-anak mendapatkan arti kata dengan prinsip tertentu, sebagaimana cara mutual exclusivity di atas. Namun hal ini masih menuai kritik.

8 Hunt, Alan dan David Beglar, Current Research and Practise in Teaching Kosakata, Methodology in Language Teaching (CUP), ( New York ; Cambridge University Press, 2002), hlm. 256

${ }_{9}^{9}$ Laura E. Berk. Development.., hlm. 249. 
Jurnal Pendidikan Agama Islam

Menurut pandangan behaviorisme, kemampuan berbicara dan memahami sebuah bahasa oleh anak diperoleh melalui rangsangan dari lingkungan luar. ${ }^{10}$ Jadi, dapat ditarik sebuah hubungan bahwa perkembangan kosakata anak juga tergantung pada masukan-masukan yang diterima anak dari luar. Hal inilah yang menyebabkan terjadinya perbedaan dalam kuantitas ragam kosakata bahasa Indonesia pada setiap anak

Pandangan alternatif mengenai hal tersebut adalah bahwa pembelajaran kata ditentukan oleh kesamaan strategi kognitif yang diterapkan anak terhadap informasi nonlinguistik. Strategi ini kemudian menjadi lebih efektif, sama efektifnya dengan pengetahuan anak tentang suatu kategori, ukuran kosakata, dan sensitifitas terhadap isyarat sosial yang dikembangkan. Anak-anak prasekolah dinilai lebih berhasil dalam memahami arti kata-kata baru dengan keberadaan beragam informasi. ${ }^{11}$

\section{e. Tata Bahasa}

Antara usia 2 dan 3 tahun, anak-anak yang bahasa ibunya English masih menggunakan kalimat yang sederhana dengan mengikuti susunan subyek-predikat-obyek. Anak yang belajar bahasa lain mengadopsi susunan kata yang dikeluarkan oleh orang dewasa. Pada dasarnya, segera sesudah anak-anak membentuk kalimat yang terdiri dari tiga kata, mereka juga membuat sedikit tambahan dan perubahan terhadap kata-kata tersebut, sehingga memungkinkan kita mengekspresikan artinya secara fleksibel dan efisien. Misalnya, anak-anak menambahkan-s untuk bentuk

10 Chaer, A.. Psikolinguistik Kajian Teoretik (Jakarta: PT. Rineka Cipta. 2003), hlm. 223

11 Laura E. Berk. Development.., hlm. 249. 
jamaknya cat, menggunakan preposisi "in" dan "on", dan membentuk variasi tenses.

Gentner menyatakan bahwa anak menguasai nomina (kata benda) dengan jumlah yang paling banyak daripada kelas kata lainnya. ${ }^{12}$ Hasil yang sama juga ditunjukkan Dardjowidjojo yang selama lima tahun meneliti pemerolehan bahasa cucunya. Dari penelitian tersebut diketahui bahwa nomina menduduki posisi paling atas dengan persentase rata-rata $49 \%$ dan verba menduduki urutan kedua dengan persentase rata-rata 29\%, selanjutnya pada urutan ketiga baru diikuti kelas kata adjektiva dengan persentase 13\%, dan kata fungsi menempati urutan keempat dengan persentase $10 \%$.

Ini menunjukkan secara berurutan anak dengan sendirinya memulainya dengan penguasaan arti kata dan kalimat yang sederhana. Segera setelah menguasai kosakata tersebut, anak kemudian menerapkannya secara konsisten dalam kehidupannya.

\section{f. Percakapan}

Selain pemerolehan kosakata dan penguasaan tata bahasa, anak harus belajar terlibat dalam komunikasi yang sesuai dan efektif. Praktik inilah yang kemudian disebut dengan kemampuan pragmatik.

Pada usia 2 tahun, anak-anak dinilai telah memiliki kemampuan dalam percakapan. Dalam interaksi face-to-face-nya, anak-anak memiliki kesempatan berbicara dan kemudian merespon lawan bicaranya. Pada usiaa 4 tahun, anak mengatur bicaranya sesuai dengan usia, jenis kelamin, dan status sosial patnernya. Misalnya, ketika bermain boneka, anak-anak

\footnotetext{
12 Dardjowidjojo, S., Psikolinguistik Pengantar Pemahaman Bahasa Manusia (Jakarta: Yayasan
} Obor Indonesia, 2010), hlm. 259 
menggunakan lebih banyak perintah/aba-aba saat memainkan peran cowok, namun ia akan berubah lebih sopan dan menggunakan ungkapan tidak langsung saat bermain peran cewek.

Kemampuan percakapan anak akan tampak kurang matang dalam situasi ketika anak tidak bisa melihat reaksi lawan bicaranya. Anak-anak cenderung menyandarkan pada bantuan khusus seperti gerak tubuh dan obyek yang dibacarakan. Namun pada usia antara 4 dan 8 tahun, kemampuan percakapan anak akan berkembang pesat. ${ }^{13}$

Dalam pola belajar berbicara umumnya terdapat empat bentuk prabicara, yakni menangis, berceloteh, isyarat, dan ungkapan-ungkapan emosi. Sebagaimana diungkapkan di muka, menangis amat sering dilakukan anak selama bulan-bulan pertamanya. Menangis adalah dasar bagi perkembangan bahasa yang sebenarnya, meskipun dari sudut jangka panjang mengoceh atau berceloteh merupakan tindakan yang paling penting karena sebenarnya inilah yang mengembangkan kemampuan berbicara anak.

Isyarat dipakai bayi sebagai pengganti bahasa, sedangkan pada anak yang lebih tua atau orang dewasa, ia digunakan sebagai pelengkap bahasa. Karena bahasa dipelajari dari proses meniru, maka bayi perlu memperoleh model atau contoh yang baik agar dapat meniru kata-kata yang baik. ${ }^{14}$

Berikut beberapa proses perkembangan bahasa pada anak: 15

\footnotetext{
${ }^{13}$ Laura E. Berk. Development.., hlm. 250.

${ }^{14}$ Elfi Yuliani Rochmah. Psikologi Perkembangan (Ponorogo: STAIN Ponorogo Press, bekerja sama dengan Penerbit Teras Yogyakarta, 2005), hlm. 128-129.

15 John W. Santrock. Psikologi Pendidikan..., hlm. 75
} 
Jurnal Pendidikan Agama Islam

\begin{tabular}{|c|c|c|}
\hline NO & $\begin{array}{l}\text { PERIODE } \\
\text { UMUR }\end{array}$ & PERKEMBANGAN ANAK \\
\hline & $0-6$ bulan & $\begin{array}{l}\text { Sekedar bersuara, membedakan huruf \& } \\
\text { berceloteh akhir periode }\end{array}$ \\
\hline & $6-12$ bulan & $\begin{array}{l}\text { Celoteh bertambah (mencakup suara dari } \\
\text { bahasa ucap), isyarat digunakan untuk } \\
\text { mengomunikasikan suatu obyek }\end{array}$ \\
\hline & 12 - 18 bulan & $\begin{array}{l}\text { Kata pertama diucapkan, rata-rata memahami } \\
50 \text { kosakata lebih }\end{array}$ \\
\hline & 18-24 bulan & Kosa kata bertambah sampai 200 buah \\
\hline & 2 tahun & $\begin{array}{l}\text { Kosa kata bertambah cepat, penggunaan } \\
\text { bentuk jamak secara tepat, penggunaan kata } \\
\text { lampau, penggunaan } \\
\text { prposisi/awalan }\end{array}$ \\
\hline & $3-4$ tahun & $\begin{array}{l}\text { Rata-rata panjang ucapan naik dari 3-4 } \\
\text { morfem per kalimat, mengunakan pertanyaan } \\
\text { ya dan tidak \& pertanyaan mengapa, dimana, } \\
\text { siapa dan kapan, menggunakan bentuk } \\
\text { negatif dan perintah, pemahaman pragmatis }{ }^{16} \\
\text { bertambah }\end{array}$ \\
\hline & $5-6$ tahun & $\begin{array}{l}\text { Kosa kata mencapai } 10.000 \text { kata, koordinasi } \\
\text { kalimat sederhana }\end{array}$ \\
\hline
\end{tabular}

\section{Perkembangan kognisi Anak}

Perkembangan adalah perubahan biologis, kognitif, dan sosioemosional yang dimulai sejak lahir dan terus berlanjut

\footnotetext{
16 Penggunaan percakapan yang tepat, ini melibatkan pengetahuan tentang konteks apa yang dikatakan dan kepada siapa serta bagaimana mengatakannya. Lihat. John W. Santrock. Psikologi..., hlm. 69
} 
disepanjang hayat.17 Proses biologis adalah perubahan dalam tubuh anak, proses ini melandasi perkembangan otak berat dan tinggi badan perubahan dalam kemampuan bergerak dan perubahan hormonal dimasa puber.

Proses kognitif adalah perubahan dalam pemikiran, kecerdasan dan bahasa anak. Proses perkembangan kogntif memampukan anak untuk mengingat puisi, membayangkan bagaimana cara memecahkan soal matematika, menyusun strategi dan menghubungkan kalimat menjadi pembicaraan yang bermakna. Sedangkan proses sosioemosional adalah perubahan dengan hubungan anak dengan orang lain perubahan dalam emosi dan perubahan dalam kepribadian.

Dalam system klasifikasi yang paling banyak dipakai, periode perkembangan meliputi: infancy (bayi), early childhood (usia balita), middle dan late childhood (periode sekolah dasar), adolescence (masa remaja), early adulthood, middle adulthood, dan late adulthood. ${ }^{18}$

Infacy merupakan periode kelahiran sampai usia 24 bulan, dimana masa ini sangat bergantung pada orang tua. early childhood (usia balita) kadang dinamakan usia pra sekolah selama periode ini anak makin mandiri dan siap untuk sekolah. Middle dan late childhood (periode sekolah dasar) dimulai umur 6-11 tahun anak mulai memiliki kemampuan membaca, menulis dan menghitung, dalam pereide ini mereka berinterakasi dengan dunia sosia yang lebih luas di luar keluarganya. Adolescence (masa remaja) adalah transisi dari masa anak-anak ke usia dewasa /usia 11-19 tahun di masa ini mereka ingin lebih bebas untuk mencari 
jatidiri, pemikiran mereka lebih logis dan dan idealis. Early adulthood (awal 20-30 tahun) ini adalah masa dimana tema cinta dan kerja lebih utama dalam kehidupannya. Periode perkembangan lainnya adalah masa dewasa tetapi akan penulis batasi pada fase yang sekiranya relevan bagi pendidikan anak.

Gambar 1 ; Proses dan periode perkembangan (Proses biologis, kognitif dan sosioemosional saling berinteraksi

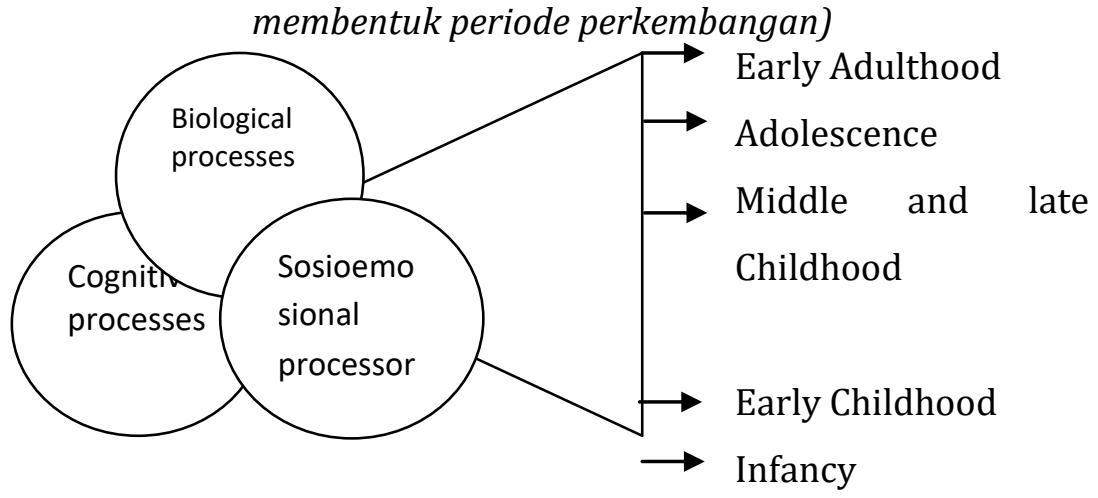

Dalam memahami perkembangan kognitif pada anak, kita mengenal sebuah teori dari Piaget. Piaget berpendapat bahwa seorang anak berkembang melalui serangkaian pikiran dari masa bayi hingga masa dewasa yang sesuai dengan masa dewasa yang sesuai dengan masing-masing tahap usia perkembangannya. ${ }^{19}$ Kemampuan bayi melalui tahap-tahap tersebut berasal dari tekanan biologis untuk menyesuaikan diri dengan lingkungannya (melalui asimilasi dan akomodasi) dan adanya pengorganisian struktur berpikir.

Teori Piaget sering disebut sebagai genetic epistemology karena teori ini berusaha melacak perkembangan kemampuan intelektual. $^{20}$ Menurutnya, tindakan yang cerdas adalah tindakan yang menimbulkan kondisi yang mendekati optimal untuk

\footnotetext{
${ }^{19}$ Muallifah, S.Psi. Psycho Islamic Smart Parenting (Yogjakarta : Diva Press, 2009), hlm. 15.

20 B.R. Hergenhahn \& Matthew H. Olson. Theories of Learning (Teori Belajar), Terj. Tri Wibowo (Jakarta : Kencana, 2008), hlm. 313
} 
kelangsungan hidup organisme artinya intelegensi memungkinkan organisme untuk menangani secara efektif lingkungannya.

Dalam memahami dunia mereka anak-anak menggunakan skema (kerangka kognitif atau kerangka referensi). Skema adalah kerangka atau konsep yang eksis di dalam pikiran individu yang dipakai untuk mengorganisasikan dan menginterpretasikan informasi. ${ }^{21}$ Sedangkan ada pula yang mengatakan skema adalah potensi untuk bertindak dengan cara tertentu. ${ }^{22}$ Seperti halnya memegang, mengisap, menggapai, dll.

Kemudian Piaget mengatakan bahwa ada dua proses yang bertanggung jawab atas cara anak menggunakan dan mengadaptasi skema mereka, yaitu; asimilasi dan akomodasi. Asimilasi terjadi ketika seorang anak memasukan pengetahuan baru kedalam pengetahuan yang sudah ada. Sedangkan akomodasi terjadi ketika anak menyesuaikan diri pada pada informasi baru, yakni anak menyesuaikan skema dengan lingkungannya. ${ }^{23}$

Kemudian organisasi adalah konsep Piaget yang berarti usaha mengelompokkan perilaku yang terpisah-pisah ke dalam urutan yang lebih teratur ke dalam system kognitif. Kemudian yang terkahir ekuilibrasi adalah suatu mekanisme yang dikemukakan Piaget untuk menjelaskan bagaimana anak bergerak dari satu tahapan pemikiran ke pemikiran selanjutnya. ${ }^{24}$

Sebagaimana Piaget, Lev Vigotsky (1896-1934) dari Rusia juga percaya bahwa anak aktif dalam menyusun pengetahuan mereka. Terkait dengan hal ini, Vigotsky memiliki tiga pandangan, yaitu :

${ }^{21}$ John W. Santrock. Psikologi Pendidikan..., hlm. 46

22 B.R. Hergenhahn \& Matthew H. Olson. Theories of Learning..., hlm. 314

23 John W. Santrock. Psikologi Pendidikan..., hlm. 46

24 Ibid, hlm. 46-47 
a. Keahlian kognitif anak dapat dipahami apabila dianalisis dan diinterpretasikan secara developmental, artinya fungsi kognitif anak dipahami dengan memeriksa asal-usulnya dan transformasinya dari bentuk awal ke bentuk selanjutnya.

b. Kemampuan kognitif dimediasi dengan kata, bahasa, dan bentuk diskursus, berfungsi sebagai alat psikologis untuk membantu dan mentransformasi aktivitas mental. Bahasa, menurutnya, pada masa kanak-kanak awal mulai digunakan sebagai alat yang membantu anak untuk merancang aktivitas dan memecahkan problem.

c. Kemampuan kognitif berasal dari relasi sosial dan dipengaruhi oleh latar belakang sosiokultural, artinya perkembangan anak tidak dapat dipisahkan dari kegiatan sosial dan kultural. ${ }^{25}$

Piaget juga menyakini bahwa perkembangan kognitif terjadi dalam empat tahapan, yaitu :

a. Sensorimotor Stage (0-2 tahun) dicirikan oleh tidak adanya bahasa.

b. Preoperational Thinking (2-7 tahun) dalam tahap ini anakanak mulai membentuk konsep sederhana dengan mengklasifikasikan benda-benda tertentu, melakukan imitasi, anak-anak memecahkan problem secara intuitif bukan berdasakan kaidah-kaidah logika.

c. Concrete Operation (7-11 tahun) kemampuan mempertahankan konservasi ${ }^{26}$,kemampuan mengelompokkan secara memadai, melakukan pengurutandan menangani konsep angka.

${ }^{25}$ Ibid., hlm. 60.

${ }^{26}$ Konservasi didefisinikan kemampuan untuk menyadari bahwa jumlah, panjang, substansi atau luas akan tetap sama meski hal-hal yang seperti itu dipresentasikan kepada anak-anak dalam bentuk yang berbeda-beda. Lihat. B.R. Hergenhahn \& Matthew H. Olson. Theories oF Learning.., hlm. 219. 
d. Formal Operations (11 dan seterusnya) dalam tahapan ini anak-anak bisa menangani situasi hipotesis, dan proses berpikirmereka tidak bergantung pada hal-hal yang langsung riil, pemikiran pada tahap ini semakin logis. ${ }^{27}$

\section{Pengaruh Bahasa Terhadap Perkembangan Kognisi Anak}

Berbicara merupakan sarana berkomunikasi. Untuk dapat berkomunikasi dengan orang lain, semua individu harus menguasai dua fungsi yang berbeda ; kemampuan menangkap maksud yang ingin dikomunikasikan orang lain dan kemampuan berkomunikasi dengan orang lain sedemikian rupa sehingga dapat dimengerti. ${ }^{28}$

Syamsu Yusuf dalam bukunya Psikologi Perkembangan bahwa bahasa merupakan kemampuan untuk berkomunikasi dengan orang lain. ${ }^{29}$ Dalam pengertian ini tercakup semua cara untuk berkomunikasi, dimana pikiran dan perasaan dinyatakan dalam bentuk lambing atau symbol untuk mengungkapkan satu pengertian seperti dengan menggunakan lisan, tulisan, isyarat bilangan, lukisan, dan mimik muka.

Sedangkan smilansky dalam beaty (1994) menemukan tiga fungsi utama bahasa pada anak, yaitu : 30

a. Meniru ucapan orang dewasa

b. Membayangkan situasi (terutama dialog), dan

c. Mengatur permainan.

Tiga fungsi berbahasa diatas dapat dilakukan di TK/PAUD melalui kegiatan mendongeng, berbagi pengalaman ataupun mengarang cerita dan puisi.

\footnotetext{
27 B.R. Hergenhahn \& Matthew H. Olson. Theories oF Learning ..,hlm. 318-320

28 Elfi Yuliani Rochmah. Psikologi Perkembangan..., hlm. 128

${ }^{29}$ Yeni Rahmawati \& Euis Kurniati. Srategi pengembangan Kreativitas Pada Anak (Jakarta : Kencana, 2010 ), hlm. 65

30 Ibid
} 
Manusia dapat berfikir tanpa menggunakan bahasa, namun bahasa mempermudah kita belajar, mengingat, memecahkan masalah dan membuat kesimpulan. Dengan bahasa seseorang dapat mengabstraksikan pengalamannya dan mengkomunikasikan pada orang lain karena bahasa merupakan media tak terbatas yang mampu mengungkapkan segala pemikiran.

Piaget memandang bahwa anak memainkan peran aktif didalam menyusun pengetahuannya mengenai realitas. Anak tidak pasif menerima informasi. Walaupun proses berfikir dalam konsepsi anak mengenai realitas telah dimodifikasi oleh pengalaman dengan dunia sekitarnya, namun anak juga berperan aktif dalam menginterpretasikan informasi yang ia peroleh melalui pengalaman, serta dalam mengadaptasikannya pada pengetahuan dan konsepsi mengenai dunia yang telah ia punyai.

Oleh karena itu, menurut Djago Tarigan (dalam bukunya Novi Resmini, dkk) bagi anak bicara tidak sekedar merupakan prestasi akan tetapi juga berfungsi untuk mencapai tujuannya, yakni: berbicara untuk menghibur, berbicara untuk menginformasikan, berbicara untuk menstimulasi, berbicara untuk meyakinkan, berbicara untuk menggerakkan. ${ }^{31}$

Jadi dapat disimpulkan bahwa berbicara adalah mengungkapkan pikiran, perasaan dan gagasan kepada orang lain agar terjalin komunikasi yang baik antara satu orang dengan orang lain. Tujuan berbicara antara lain adalah tujuan menghibur orang, menginformasikan suatu pesan, memberikan rangsangan kepada pendengar agar melakukan apa yang dikehendaki oleh pembicara. Berbicara dapat meyakinkan pendengar agar menyakini,

31 Novi Resmini,. Bahan Belajar Mandiri: Pembinaan dan Pengembangan Pembalajaran Bahasa dan Sastra Indonesia (Bandung: UPI Pers. 2006), hlm. 193 
memahami dan menututi kebenaran dari pembicara. Berbicara dengan tujuan menstimulasi dan meyakinkan dapat menggerakkan pendengar yang mendengarkan untuk melakukan apa yang dikehendaki pembicara.

Bahasa yang diwujudkan dalam sebuah kata-kata adalah bentuk representasi dari sebuah fakta, yang pada akhirnya akan mengklasifikasikan dalam kategori yang berbeda-beda dan memunculkan perbedaan budaya dengan budaya yang lain. Seperti halnya, dunia mental orang Indonesia dengan orang Inggris akan berbeda, ini tidak lepas dari factor factor bahasa yang digunakannya. Belum lagi, status sosial juga dapat berpengaruh pada kebahasaan mereka yang akan berakibat pada pola pikir yang digunakan nantinya.

Dengan menggunakan bahasa ide menjadi obyektif sehingga pikiran yang sebelumnya berada di awing-awang mampu disimpulkan dengan bentuk yang konkret, yang nantinya dapat obyek yang mampu dirasakan dan dinikmati masyarakat luas. Ketika satu bahasa dapat mencetak perilaku dan kemudian perilaku dilakukan secara terus menerus tidak menutup kemungkinan bahasa akan muncul menjadi sebuah kepribadian. Hal ini tidak lepas dari kebiasaan yang dulunya dibentuk oleh manusia, dan karena kebiasaan itu sudah berlaku pada akhirnya manusialah yang akan dibentuk dari kebiasaan itu.

Pengenalan bahasa yang lebih dini dibutuhkan untuk memperoleh keterampilan bahasa yang baik. Perkembangan bahasa dipengaruhi oleh 5 faktor, yaitu: intelegensi, status sosial 
sosial, jenis kelamin, hubungan keluarga, dan kedwibahasaan (Pemakaian dua bahasa). ${ }^{32}$

Secara rinci dapat diidentifikasi sejumlah faktor yang mempengaruhi perkembangan bahasa, yaitu:

1. Inteligensia

Tinggi rendahnya kemampuan kognisi individu akan mempengaruhi cepat lambatnya perkembangan bahasa individu. Ini relevan dengan pembahasan sebelumnya bahwa terdapat korelasi yang signifikan antara pikiran dengan bahasa seseorang

2. Status sosial

Anak yang secara social budaya berasal dari kalangan atas dan menengah lebih cepat perkembangan bahasanya daripada anak yang berasal dari kalangan bawah. Anak dari kalangan menengah ke atas dapat mencapai peringkat tertinggi dalam prestasi kebahasaan secara fundamental, hal ini berpulang pada motif kebahasaan yang mereka terima dan adanya penguatan atas respon mereka.

3. Jumlah anak atau jumlah keluarga

Suatu keluarga yang memiliki banyak anggota keluarga, perkembangan bahasa anak lebih cepat, karena terjadi komunikasi yang bervariasi dibandingkan dengan yang hanya memiliki anak tunggal dan tidak ada anggota lain selain keluarga inti.

4. Jenis kelamin

Anak perempuan melebihi anak laki-laki dalam aspek bahasa. Anak perempuan lebih dahulu mampu berbicara daripada

32 Syakir Abdul Azhim, Membimbing Anak Terampil Berbahasa, (Depok : Gema Insani Press, 2011), hlm. 37-38 
anak laki-laki dan kamus kosakatanya lebih banyak daripada anak laki-laki. Namun perbedaan jenis kelamin ini akan berkurang secara tajam selaras dengan berguliranya fase perkembangan dan bertambahnya usia.

5. Kedwibahasaan

Anak yang dibesarkan dalam keluarga yang menggunakan bahasa lebih dari satu atau lebih bagus dan lebih cepat perkembangan bahasanya daripada yang hanya menggunakan satu bahasa saja karena anak terbiasa menggunakan bahasa secara bervariasi. Misalnya, di dalam rumah dia menggunakan bahasa jawa dan di luar rumah dia menggunakan bahasa Indonesia.

Karakteristik perkembangan bahasa remaja sesungguhnya didukung oleh perkembangan kognitif yang menurut jean Piaget telah mencapai tahap operasional formal. Sejalan dengan perkembangan kognitifnya, remaja mulai mampu mengaplikasikan prinsip-prinsip berpikir formal atau berpikir ilmiah secara baik pada setiap situasi dan telah mengalami peningkatan kemampuan dalam menyusun pola hubungan secara komperhensif, membandingkan secara kritis antara fakta dan asumsi dengan mengurangi penggunaan symbol-simbol dan terminologi konkret dalam mengomunikasikannya.

\section{Hubungan bahasa dan pikiran (kognisi)}

Keterkaitan antara bahasa dan pikiran pada dasarnya terletak pada asumsi bahwa bahasa mempengaruhi cara pandang manusia terhadap dunia, serta mempengaruhi pikiran individu pemakai bahasa tersebut. Keterkaitan antara keduanya dimungkinkan karena berpikir adalah upaya untuk 
mengasosiasikan kata atau konsep untuk mendapatkan satu kesimpulan melalui media bahasa.

Beberapa ahli mencoba memaparkan bentuk hubungan antara bahasa dan pikiran, atau lebih disempitkan lagi, bagaimana bahasa mempengaruhi pemikiran manusia. Berikut ungakapan bebrapa ahli tentang bahsa dan pikiran.

1. Teori Sapir Whorf

Edward Sapir dan B. L. Whorf adalah linguis amerika yang mengatakan bahwa manusia hidup di dunia di bawah 'belas kasih' bahasanya yang telah menjadi alat pengantar dalam kehidupan bermasyarakat.

Saphir dan Whorf mengatakan bahwa tidak ada dua bahasa yang memiliki kesamaan untuk dipertimbangkan sebagai realitas sosial yang sama. Saphir dan Whorf menguraikan dua hipotesis mengenai keterkaitan antara bahasa dan pikiran.

Hipotesis pertama adalah lingusitic relativity hypothesis yang menyatakan bahwa perbedaan struktur bahasa secara umum paralel dengan perbedaan kognitif non bahasa (nonlinguistic cognitive). Perbedaan bahasa menyebabkan perbedaan pikiran orang yang menggunakan bahasa tersebut.

Hipotesis kedua adalah linguistics determinism yang menyatakan bahwa struktur bahasa mempengaruhi cara inidvidu mempersepsi dan menalar dunia perseptual. Dengan kata lain, struktur kognisi manusia ditentukan oleh kategori dan struktur yang sudah ada dalam bahasa

2. Teori Jean Piaget

Berbeda dengan apa yang disampaikan oleh Saphir dan Whorf, sebaliknya menurut Piaget justru pikiranlah yang membentuk bahasa, tanpa pikiran bahasa tidak akan ada. Piaget 
mengemukakan ada dua hal penting mengenai hubungan bahasa dengan kegiatan-kegiatan intelek (pikiran), yaitu: Sumber kegiatan intelek tidak terdapat dalam bahasa, tetapi dalam periode sensorimotorik ( 2 tahun pertama perkembangan kognisi), yakni satu system skema, dikembangkan secara penuh, dan membuat lebih dahulu gambaran-gambaran dari aspek-aspek struktur golongan-golongan dan hubunganhubungan benda-benda (sebelum mendahului gambarangambaran lain) dan bentuk-bentuk dasar penyimpanan dan operasi pemakaian kembali.

Pembentukan pemikiran yang tepat dikemukakan dan berbentuk terjadi pada waktu yang bersamaan dengan pemerolehan bahasa. Keduanya milik suatu proses yang lebih umum, yaitu konstitusi fungsi lambang pada umumnya.

\section{Teori L. S.Vygotsky}

Teori ini di lontarkan oleh L.S Vygotsky, dan ia mengatakan bahwa terdapat satu tahap perkembangan bahasa sebelum adanya pikiran, dan adanya satu tahap perkembangan pikiran sebelum adanya bahasa. Lalu, dua garis perkembangan ini saling bertemu maka pikiran berbahasa dan bahasa berpikir terjadi secara serentak. Maksudnya, pikiran dan bahasa pada mulanya berkembang secara terpisah, tidak saling mempengaruhi satu sama lain, dengan kata lain, mula-mula pikiran berkembang tanpa bahasa, begitu pula sebaliknya, bahasa pada mulanya berkembang tanpa pikiran, kemudian pada tahap selanjutnya, keduanya bertemu, bekerjasama, dan saling mempengaruhi. ${ }^{33}$

\footnotetext{
${ }^{33}$ Chaer, A.. Psikolinguistik ..., hlm. 52-55
} 
Dari uraian para ahli mengenai hubungan antara bahasa dan pikiran dapat dikelompokkan menjadi tiga kelompok diantaranya:

a. Bahasa mempengaruhi pikiran. Pikiran manusia dapat terkondisikan oleh kata yang digunakan. Tokoh yang mendukung hubungan ini adalah Benyamin Whorf dan gurunya, Edward Saphir. Whorf mencontohkan, orang Jepang memiliki pikiran yang sangat tinggi karena mereka mempunyai banyak kosakata dalam menjelaskan sebuah realitas. Hal ini membuktikan bahwa mereka memiliki pemahaman mendetail tentang realitas.

b. Pikiran mempengaruhi bahasa. Jean Piaget mengungkapkan bahwa perkembangan aspek kognitif akan mempengaruhi bahasa yang digunakan. Semakin tinggi aspek tersebut, semakin tinggi bahasa yang digunakannya.

c. Bahasa dan pikiran saling mempengaruhi. Menurut Vigotsky, kata-kata dan pikiran memiliki hubungan timbal balik. Maka dari itu, keduanya saling mempengaruhi.

Keterkaitan bahasa dan pikiran akan selalu menjadi satu bagian, dimana antara satu dengan yang lainnya saling melengkapi dan tidak bisa dipisah sebagai pengaruh atas keduanya. Dari uraian diatas dapat disimpulkan bahwa bahasa mampu mengubah pikiran melalui beberapa formulasi, diantaranya:

a. Bahasa meningkatkan komunikasi.

b. Bahasa memperluas pikiran dengan adanya abstraksi.

c. Bahasa membentuk kebudayaan.

d. Bahasa dapat membangun verbal self concept. 


\section{SIMPULAN}

Dari pembahasan di atas, bahasa dan pikiran (kognitif) anak memiliki hubungan yang berkaitan dan saling mempengaruhi satu sama lain. Bahasa menjadi media transformasi bagi suatu obyek atas pengetahuan yang ada di sekitarnya dan menjadi alat komunikasi dalam penyampaian pesan agar mampu diterima, baik sebagai ide ataupun isyarat dan lain sebagainnya.

Perbendaharaan kosakata sangat berpengaruh pada ketrampilan berbahasa yang lain. Banyaknya kosakata yang dihasilkan oleh seseorang dapat mencerminkan tingkat intelektualitas dari orang tersebut. Kuantitas ragam kosakata bahasa pada anak berbeda antara satu dengan yang lain. Hal ini dipengaruhi oleh beberapa faktor, di antaranya adalah inteligensia, jenis kelamin, dan kondisi lingkungan. Di samping itu, perbedaan masukan (input) yang diterima masing-masing anak juga turut berpengaruh dalam kuantitas ragam kosakata yang dikuasai anak. 


\section{DAFTAR PUSTAKA}

A. Martuti. Mendirikan dan Mengelola PAUD, Manajemen Administrasi dan Strategi Pembelajaran. Yogjakarta: Kreasi Wacana, 2009.

Azhim, Syakir Abdul. Membimbing Anak Terampil Berbahasa. Depok: Gema Insani Press, 2011

B.R. Hergenhahn \& Matthew H. Olson. Theories oF Learning (Teori Belajar) , Terj. Tri Wibowo. Jakarta: Kencana, 2008.

Berk, Laura E. Development through the Lifespan. Boston: Pearson, 2007.

Chaer, A. Psikolinguistik Kajian Teoretik. Jakarta: PT. Rineka Cipta. 2003.

Dardjowidjojo, S. Psikolinguistik Pengantar Pemahaman Bahasa Manusia. Jakarta: Yayasan Obor Indonesia, 2010.

Elfi Yuliani Rochmah. Psikologi Perkembangan. Ponorogo: STAIN Ponorogo Press, bekerja sama dengan Penerbit Teras Yogyakarta, 2005.

Hunt, Alan dan David Beglar. Current Research and Practise in Teaching Kosakata, Methodology in Language Teaching (CUP). New York ; Cambridge University Press, 2002.

Mansur. Pendidikan Anak Usia Dini dalam Islam. Yogyakarta: Pustaka Pelajar, 2009.

Muallifah. Psycho Islamic Smart Parenting. Yogyakarta: Diva Press, 2009.

Resmini, Novi. Bahan Belajar Mandiri: Pembinaan dan Pengembangan Pembalajaran Bahasa dan Sastra Indonesia. Bandung: UPI Pers. 2006.

Santrock, John W. Psikologi Pendidikan, terj. Tri Wibowo B.S. Jakarta: Kencana, 2007.

Yeni Rahmawati \& Euis Kurniati. Srategi pengembangan Kreativitas Pada Anak. Jakarta: Kencana, 2010. 